\title{
新型抗广谱性除草剂草甘膦转基因油菜的创制及其鉴定
}

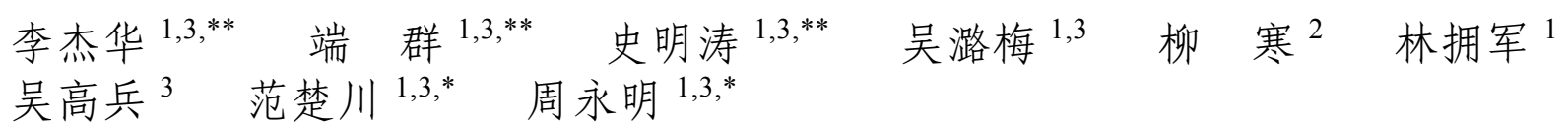

${ }^{1}$ 华中农业大学作物遗传改良国家重点实验室, 湖北武汉 $430070 ;{ }^{2}$ 浙江省农业科学院, 浙江杭州 $310021 ;{ }^{3}$ 华中农业大学植物科学 技术学院, 湖北武汉 430070

摘 要: 草甘膦是世界上应用最广泛的广谱性除草剂, 目前我国还没有自主知识产权的抗草甘膦油菜品种。本研究 利用农杆菌介导的油菜下胚轴遗传转化方法, 将新型抗草甘膦基因 I. variabilis EPSPS 转入甘蓝型油菜品系 J9707 中, 获得了 126 株阳性转化株，阳性率为 $97.0 \%$ 。这些转化单株中的 T-DNA 插入以单拷贝为主(占 $44.8 \%$ )。通过反向 PCR 确定了 EPS-2、EPS-6 和 EPS-7 等油菜转化体中 T-DNA 插入位置, 并设计转化体特异性引物对它们的 $\mathrm{T}_{0} \sim \mathrm{T}_{3}$ 代材料 进行检测, 证明了它们的 T-DNA 在基因组水平上整合的稳定性。RNA 和蛋白水平的表达分析证实, I. variabilis EPSPS 转基因及其蛋白产物在各转化株系不同世代能够稳定表达。苗期进行不同剂量的除草剂喷施处理发现, EPS-1、 EPS-2、EPS-5、EPS-6 和 EPS-7 等株系可耐受 4 倍田间推荐使用剂量的草甘膦。本研究所创建的新型抗草甘膦油菜 种质资源将为我国抗除草剂油菜品种培育奠定了重要基础。

关键词: 甘蓝型油菜; I. variabilis EPSPS；转基因；草甘膦；分子特征

\section{Development and identification of transgenic rapeseed with a novel gene for glyphosate resistance}

LI Jie-Hua ${ }^{1,3,{ }^{* *}}$, DUAN Qun ${ }^{1,3,{ }^{* *}}$, SHI Ming-Tao ${ }^{1,3,{ }^{* *}}$, WU Lu-Mei ${ }^{1,3}$, LIU Han ${ }^{2}$, LIN Yong-Jun ${ }^{1}$, WU Gao-Bing $^{3}$, FAN Chu-Chuan ${ }^{1,3, *}$, and ZHOU Yong-Ming ${ }^{1,3, *}$

${ }^{1}$ National Key Laboratory of Crop Genetic Improvement, Huazhong Agricultural University, Wuhan 430070, Hubei, China; ${ }^{2}$ Zhejiang Academy of Agricultural Sciences, Hangzhou 310021, Zhejiang, China; ${ }^{3}$ College of Plant Science \& Technology, Huazhong Agricultural University, Wuhan 430070, Hubei, China

\begin{abstract}
Glyphosate is the most widely used broad-spectrum herbicide in the world. However, at present there is no glyphosate-tolerant rapeseed variety with independent intellectual property rights in China. In the study, a novel glyphosate-resistant genes I. variabilis EPSPS was transferred to the Brassica napus pure line $\mathrm{J} 9707$ via the Agrobacterium tumefaciens-mediated hypocotyl method, and $126 \mathrm{~T}_{0}$-positive transgenic plants with $97.0 \%$ positive rate were generated. The T-DNA insertion with a single copy (44.8\%) is dominant. The insertion locations of T-DNA in the lines of EPS-2, EPS-6, and EPS-7 were identified by inverse PCR method. The stability of the T-DNA insertion in these lines were further confirmed by insertion-specific PCR in their $\mathrm{T}_{0}$ to $\mathrm{T}_{3}$ plants. The gene expression analysis revealed that the I. variabilis EPSPS gene and its protein was stably expressed in different generations of transgenic lines in RNA and protein levels. Treatments with different doses of glyphosate indicated that the lines of EPS-1, EPS-2, EPS-5, EPS-6, and EPS-7 could tolerate four times of the recommended dose of glyphosate in production. Thus, the novel glyphosate-tolerant rapeseed lines generated in the present study will lay the foundation for the herbicidetolerance rapeseed breeding in China.
\end{abstract}

Keywords: Brassica napus; I. variabilis EPSPS; transgene; glyphosate; molecular characteristics

\footnotetext{
本研究由国家转基因生物新品种培育重大专项(2018ZX08020001)资助。

This study was supported by the National Major Project for Developing New GM Crops (2018ZX08020001).

* 通信作者(Corresponding authors)：范楚川, E-mail: fanchuchuan@mail.hzau.edu.cn; 周永明, E-mail: ymzhou@mail.hzau.edu.cn

** 同等贡献(Contributed equally to this work)

第一作者联系方式: 李杰华,E-mail: 1023629768@qq.com; 端群,E-mail: 554246233@qq.com; 史明涛, E-mail: 843121993@qq.com

Received (收稿日期): 2020-07-25; Accepted (接受日期): 2020-11-13; Published online (网络出版日期): 2020-12-14.

URL: https://kns.cnki.net/kcms/detail/11.1809.S.20201214.1615.002.html
} 
油菜是我国重要的油料作物, 常年种植面积约 700 多万公顷, 菜籽油占国产油料作物产油量的 $55 \%$ 以上，是国产食用植物油的第一大来源，在维 护国家食用油供给安全战略中居于核心地位 ${ }^{[1]}$ 。杂 草危害是造成油菜减产的主要因素。杂草与油菜竞 争水、肥等生存资源, 影响油菜正常生长发育, 可导 致产量平均下降 $15.8 \%$, 严重时可达 $50 \%$ 以上 ${ }^{[2]}$ 。油 菜田间杂草可通过人工除草和施用化学除草剂防 治。人工除草耗工耗力, 大幅增加了田间用工成本、 制约了油菜的机械化规模化种植, 导致生产效率和 农民收益降低; 培育抗除草剂油菜新品种是油菜机 械化、规模化种植的必要配套措施, 可解决大田除 草的问题, 有效降低生产成本。

草甘膦是一种非选择性除草剂, 其作用靶标为 莽草酸路径中的关键酶 5-烯醇式丙酮酰莽草酸-3-磷 酸合成酶 (5-enolpyruvyl-shikimate-3-phosphate synthase, EPSPS); 通过抑制 EPSPS 的活性, 阻断莽草 酸途径, 导致植物芳香族氨基酸(色氨酸、酪氨酸、 苯丙氨酸)的生物合成受到抑制和莽草酸在植物体 内过量积累, 最终引起植物体内代谢混乱和植物死 $亡^{[3]}$ 。作为应用最为广泛的广谱性除草剂之一, 草甘 膦具有除草效率高、成本低、生态风险小等优势。

在 2015 年全球农药市场调查中, 草甘膦以 49.65 亿 美元的销售额位居除草剂销售额榜首 ${ }^{[4]}$ 。

目前抗草甘膦作物的培育主要通过常规的诱变 育种和转基因育种来实现。诱变育种是在细胞或组 织培养基中添加除草剂进行篮选, 以及通过对花 粉、小孢子、种子等诱变处理后进行篮选, 获得抗 性材料; 利用该方法已在油菜、水稻和大豆等多种 作物中获得了具有草甘膦抗性的突变体 ${ }^{[5-7]}$ 。而转基 因育种是利用从从微生物或植物体中分离出抗性基 因，通过遗传转化载体导入作物基因组中来实现; 利用该方法已成功培育了大豆、油菜、棉花、玉米 等多种抗草甘膦作物 ${ }^{[8-11]}$, 是目前发展迅速、应用最 为广泛和有效的抗草甘膦育种方法。在转基因育种 中, 利用的抗草甘膦基因主要有 3 种: (1)突变后的 I 型 EPSPS 基因。例如, Comai 等 ${ }^{[12]}$ 从鼠伤寒沙门氏 菌中分离得到具有草甘膦抗性的 aro $A$ 基因, 并将其 转入烟草获得了抗草甘膦转基因烟草; (2)天然的抗 草甘膦 II 型 $E P S P S$ 基因。例如, 孟山都公司从根 癌农杆菌 CP4 菌株中获得的抗草甘膦 cp4-epsps 基因 ${ }^{[13]}$; (3)草甘膦降解基因。例如, 来源于苍白杆菌 的 gox 基因 ${ }^{[14]}$ 。目前商业化应用的草甘膦抗性基因 主要包含 CP4-epsps、mepsps、2mepsps、epsps $(\mathrm{Ag})$ 、 grg、gat4601、gat4621 等, 其中应用最为广泛的是 CP4-epsps 基因 ${ }^{[8,15]}$ 。利用这些基因培育的抗草甘膦 油菜已在美国、加拿大、澳大利亚等国家实现了广 泛的商业化应用。但是这些基因资源的知识产权绝 大部分被国外生物技术公司所垄断，极大限制了我 国油菜抗除草剂品种的培育及其产业化的发展。近 年来, 随着基因编辑技术的快速发展, 对植物体内 EPSPS 基因的保守氨基酸进行精准的碱基替换, 也 成功获得了抗草甘膦的水稻和木薯 ${ }^{[16-17]}$, 为除草剂 作物的培育提供了新方法。但是, 该方法在不同作 物中的应用还有赖于单碱基编辑技术的建立。

非敏感 EPSPS 合酶基因 I. variabilis EPSPS 是华 中农业大学从放线菌属变异白蚁菌 (Isoptericola variabilis)中克隆到的草甘膦抗性基因 ${ }^{[18]}$ 。该基因编 码的蛋白不具有 CP4-EPSPS 专利保护的 4 条保守序 列, 但保留了对草甘膦较高的耐受性, 是具有完全 自主知识产权的抗除草剂基因资源 ${ }^{[19]}$ 。利用该基因 创制的水稻转化体可以耐受 $8400 \mathrm{~g} \mathrm{hm}^{-2}$ 高剂量的草 甘膦, 显示出良好的应用前景 ${ }^{[18]}$ 。本研究旨在利用 该基因创制新型的抗草甘膦油菜种质资源，为培育 抗除草剂转基因新品种奠定基础, 从而为我国油菜 大田生产的杂草治理提供新的解决方案。

\section{1 材料与方法}

\section{1 试验材料及其种植}

用于遗传转化的甘蓝型油菜受体品系为 J9707, 是本实验室䇻选获得的具有高遗传转化效率的半冬 性低芥酸品系。常规品种中双 11 号由华中农业大学 国家油菜工程技术中心提供。转基因 $\mathrm{T}_{0}$ 代材料在昼 /夜 $16 \mathrm{~h} / 8 \mathrm{~h} 、 22^{\circ} \mathrm{C} / 18^{\circ} \mathrm{C}$ 、光照强度 $115 \sim 144 \mu \mathrm{mol} \mathrm{m} \mathrm{m}^{-2} \mathrm{~s}^{-1}$ 的培养室内种植。其后代材料种植于华中农业大学 校内油菜转基因试验基地。

\section{2 植物载体及其遗传转化}

本研究所用的草甘膦抗性基因 $E P S P S$ 是从放线菌 属变异白蚁菌中克隆得到, 命名为 I. variabilis

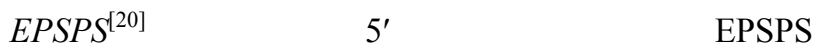
蛋白的叶绿体信号肽序列(chloroplast transit peptide, CTP; GenBank: CAA29828.1), 具有将表达出的 EPSPS 蛋白运送到芳香族氨基酸的合成场所叶绿体中的功能。 然后, 将其替换 pCAMBIA1300 质粒中的潮霉素基因, 获得具有 CaMV 35S 启动子和 CaMV poly(A)终止子的 I. variabilis EPSPS 超量表达载体 pTGH-1 (图 1)。

遗传转化采用农杆菌介导的油菜下胚轴遗传转 化法 ${ }^{[21]}$ 。 


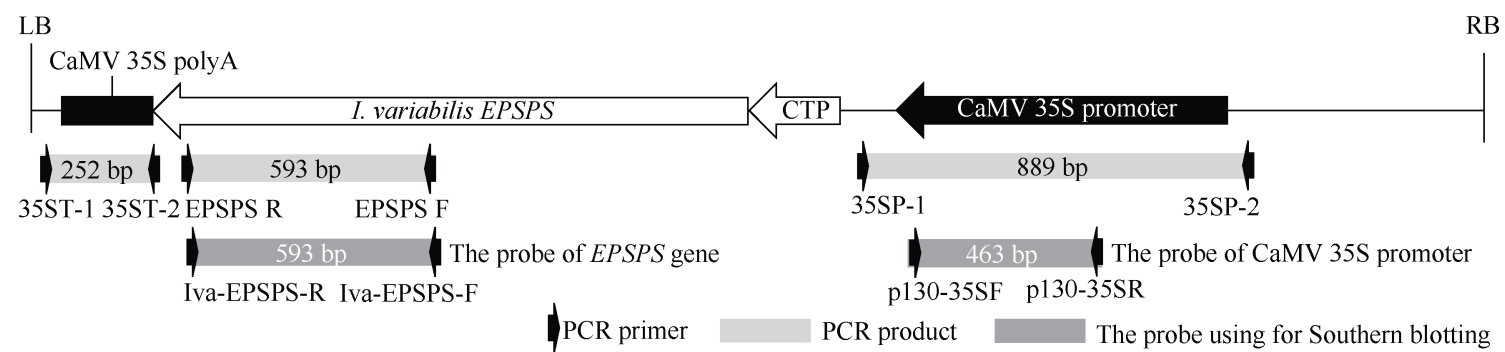

图 1 pTGH-1 质粒的 T-DNA 示意图

Fig. 1 T-DNA region of the binary construct pTGH-1

1.3 转基因植株的阳性和转化体特异性的 PCR 检测

设计 3 对特异性引物 EPSPS-F/EPSPS-R、 $35 \mathrm{SP}-1 / 35 \mathrm{SP}-2$ 和 $35 \mathrm{ST}-1 / 35 \mathrm{ST}-2$ 分别用于检测 pTGH-1 载体 T-DNA 区的目的基因 I. variabilis EPSPS、CaMV 35S 启动子元件和 CaMV 35S 终止子 元件(图 1)。

利用分离的 T-DNA 插入位点侧翼序列信息，设 计油菜转化体的特异性上游引物, 分别与位于 T-DNA 的 LB 端的共同下游引物(P5)进行组合，用于 转化体特异性 PCR 检测。PCR 扩增体系含 $50 \mathrm{ng} \mu \mathrm{L}^{-1}$ 的模板 DNA $2.0 \mu \mathrm{L} 、 10 \times$ PCR buffer $1.0 \mu \mathrm{L} 、 2 \mathrm{mmol} \mathrm{L}^{-1}$ dNTPs $0.8 \mu \mathrm{L} 、 10 \mu \mathrm{mol} \mathrm{L}^{-1}$ 引物各 $0.4 \mu \mathrm{L} 、 2 \mathrm{U}_{\mu} \mathrm{L}^{-1} \mathrm{Taq}$ DNA 聚合酶 $0.15 \mu \mathrm{L}$, 添加 $\mathrm{ddH}_{2} \mathrm{O}$ 至 $10 \mu \mathrm{L}$ 。 $\mathrm{PCR}$ 扩增程序为 $94^{\circ} \mathrm{C}$ 预变性 $4 \mathrm{~min} ; 94^{\circ} \mathrm{C}$ 变性 $30 \mathrm{~s}, 56^{\circ} \mathrm{C}$ 退火 $30 \mathrm{~s}, 72^{\circ} \mathrm{C}$ 延伸 $30 \mathrm{~s}$, 扩增 32 个循环; 最后 $72^{\circ} \mathrm{C}$ 延伸 $10 \mathrm{~min}$ 。PCR 产物在 $1.0 \%$ 琼脂糖凝胶上进行电 泳和照相观察。所有引物序列见表 1 。

\subsection{Southern blot 检测转基因拷贝数}

在目的基因 I. variabilis EPSPS 和 CaMV $35 \mathrm{~S}$ 启动子上分别设计特异性引物对 Iva-EPSPS-F/ Iva-EPSPS-R 和 $\mathrm{p} 130-35 \mathrm{sF} / \mathrm{p} 130-35 \mathrm{sR}$, 并 对 pTGH-1 质粒进行扩增, 用于制备 EPSPS 探针和 CaMV 35S promoter 探针(图 1)。油菜基因组 DNA 的提取、酶切、电泳和转膜、DNA 探针的制备、 杂交和检测等具体程序见李杰华 ${ }^{[22]}$ 的方法。引物序 列见表 1 。

\section{5 转化单株中的 T-DNA 插入位点鉴定}

利用反向 PCR 的方法分离转基因的 T-DNA 插 入位点。具体程序见李杰华 ${ }^{[22]}$ 的方法。第 1 轮 PCR 引物为 $\mathrm{P} 1 / \mathrm{SP} 2$, 第 2 轮 $\mathrm{PCR}$ 引物为 $\mathrm{P} 3 / \mathrm{SP} 3$, 引物序 列见表 1 所示。以 SP3 引物进行 PCR 产物测序。将 克隆得到的序列与甘蓝型油菜参考基因组序列 (http://www.genoscope.cns.fr/brassicanapus/) 进行比 对和分析, 确定 T-DNA 插入在油菜基因组中的具体 位点。

表 1 本研究所用引物序列

Table 1 Primer sequences used in this study

\begin{tabular}{ll||ll}
\hline $\begin{array}{c}\text { 引物名称 } \\
\text { Primer name }\end{array}$ & \multicolumn{1}{c||}{$\begin{array}{c}\text { 引物序列 } \\
\text { Primer sequence }\left(5^{\prime}-3^{\prime}\right)\end{array}$} & $\begin{array}{c}\text { 引物名称 } \\
\text { Primer name }\end{array}$ & \multicolumn{1}{c}{$\begin{array}{c}\text { 引物序列 } \\
\text { Primer sequence }\left(5^{\prime}-3^{\prime}\right)\end{array}$} \\
\hline EPSPS-F & ATTAGCGCTAGGGACGTGAG & P1 & CTCTAGCCAATACGCAAACCGCC \\
EPSPS-R & ATACGCTCCCACATCCTGTC & P3 & TGTTGTGTGGAATTGTGAGCGGA \\
35 SP-1 & GAAACCGGTTACAGGCAAATG & SP2 & CAGGTGGAGAACGTCGGTACGACT \\
35 SP-2 & AGAGGCGGTTTGCGTATT & SP3 & GGGTTTCGCTCATGTGTTGAGCA \\
35 ST-1 & ATAACACATTGCGGACGTTT & BnACT-qRTF & CTGGAATTGCTGACCGTATGAG \\
35 ST-2 & AGCCGGTGCTTGATAACT & BnACT-qRTR & ATCTGTTGGAAAGTGCTGAGGG \\
35 SP-2 & AGAGGCGGTTTGCGTATT & EPs-qRTF & CAGGGATGGACTCGTTATCAC \\
p130-35sF & CAAGTGGATTGATGTGATAACATG & EPs-qRTR & GAGGGTCTTCGCAGTCGT \\
p130-35sR & GTAGAGAGAGACTGGTGATTTCAGC & EPSPS6 F & GGCTTCTTAGTGGGCCTTTC \\
Iva-EPSPS-F & ATTAGCGCTAGGGACGTGAG & EPSPS7 F & CATCCGCTTTACGACGAAACT \\
Iva-EPSPS-R & ATACGCTCCCACATCCTGTC & EPSPS2 F & GAACTGAGCATGAATGGCATAAA \\
& & P5 & ATGTGTGAGTAGTTCCCAGATAAGG \\
\hline
\end{tabular}




\section{6 基因表达量检测}

抽提油菜不同组织的 RNA 进行 RT-PCR (reversed transcript polymerase chain reaction)和 qRTPCR (quantitative real-time PCR)的基因表达量检测。 RNA 抽提、反转录和 RT-PCR 等程序详见 Fan 等 ${ }^{[23]}$ 的方法。I. variabilis EPSPS 和内参基因 ACTIN2 的 表达检测引物对分别为 EPs-qRTF/EPs-qRTR 和 BnACT-qRTF/ BnACT-qRTR，序列详见表 1。qRT-PCR 反应体系包含 cDNA 模板 $4 \mu \mathrm{L} 、 2 \times \mathrm{SYBR}$ Green Mix $10 \mu \mathrm{L} 、 2.5 \mu \mathrm{mol} \mathrm{L}{ }^{-1}$ 的引物各 $2 \mu \mathrm{L}$, 加 $\mathrm{ddH}_{2} \mathrm{O}$ 至总体 积 $20 \mu \mathrm{L}$ 。 $\mathrm{PCR}$ 反应程序为 $95^{\circ} \mathrm{C}$ 变性 $3 \mathrm{~min} ; 95^{\circ} \mathrm{C}$ 变性 $12 \mathrm{~s}, 60^{\circ} \mathrm{C}$ 退火 $30 \mathrm{~s}, 72^{\circ} \mathrm{C}$ 延伸 $30 \mathrm{~s}, 45$ 个循环。以 $A C T I N 2$ 作为对照, 目的基因的 $\mathrm{Ct}$ 值减去 $A C T I N$ 的 $\mathrm{Ct}$ 值得到 $\Delta C t$, 计算 $2^{(\Delta C \mathrm{C})}$ 即为相对表达量的值。

用 Western blot 方法对转化体叶片中的 I. variabilis EPSPS 蛋白表达量进行检测, 以油菜 ACTIN2 为内参基因, 以转化受体 $\mathrm{J} 9707$ 为阴性对照。油菜叶 片的蛋白提取、蛋白浓度测定和 Western blot 检测等 具体程序见李杰华 ${ }^{[22]}$ 的方法。

\section{7 除草剂抗性检测}

待油菜长出 5 6 片真叶时, 对各材料进行除草 剂草甘膦的喷施处理, 以 $\mathrm{J} 9707$ 为阴性对照。除草剂 施用剂量设置 0 倍(喷施等量清水)、生产上推荐剂量 的 1 倍(450 $\mathrm{g} \mathrm{hm}^{-2}$ 农达异丙胺盐制剂)、2 倍(900 $\mathrm{g} \mathrm{hm}^{-2}$ $41 \%$ 农达异丙胺盐制剂)和 4 倍(1800 $\mathrm{g} \mathrm{hm}^{-2}$ 农达异 丙胺盐制剂)。在喷施处理前、喷施处理后 1 4 周内 观察和调查抗性表现。

\section{2 结果与分析}

\section{1 甘蓝型油菜 I. Variabilis EPSPS 转基因材料} 创建及其阳性鉴定

将转化载体 pTGH-1 通过电击法转入农杆菌 GV3101 中, 然后通过农杆菌介导的油菜下胚轴遗 传转化法导入到 J9707 中。由于 pTGH-1 中不含篮 选标记基因, 因此在油菜转化过程中利用目的基因 I. variabilis EPSPS 进行筛选, 分别在愈伤诱导和分化 阶段添加 $30 \mathrm{mg} \mathrm{L}^{-1}$ 的草甘膦, 而在其他阶段中没有施 加选择压。最终, 经过侵染、共培养、愈伤诱导、分 化、生根和移苗等转化过程, 共获得 130 个抗性植株。

为了确定这些抗性植株的基因组中转化载体的 功能元件整合情况, 利用 3 对特异性引物 EPSPS-F/ EPSPS-R、35SP-1/35SP-2 和 35ST-1/35ST-2 分别检 测 pTGH-1 载体 T-DNA 区的目的基因 I. variabilis
EPSPS、CaMV 35S 启动子元件和 CaMV 35S 终止子 元件(图 1)发现, 126 株含有完整外源插入序列的目 的功能片段, 转基因阳性率为 97\% (图 2)。

\section{2 阳性转化单株的拷贝数检测}

针对 I. variabilis EPSPS 基因设计探针(图 1)，采 用 Southern blot 技术对 96 份 $\mathrm{T}_{0}$ 代阳性转化单株进 行了转基因拷贝数检测。如图 3 所示, 转基因单株 中的 T-DNA 插入存在 1 12 个拷贝的变异, 其中单 拷贝个体占 $44.8 \%$ ，两拷贝和三拷贝个体分别占 $15.6 \%$ 和 $11.5 \%$ 。表明本研究所采用的农杆菌介导的 油菜下胚轴遗传转化法以及采用的草甘膦选择压有 利于单拷贝和低拷贝转基因株系的产生。

根据 $\mathrm{T}_{0}$ 代拷贝数检测结果, 同时结合它们后代 株系的田间表现, 选择具有 1 2 个拷贝的优良株系 的后代进行了拷贝数验证。分别采用 Hind III 和 $E c o \mathrm{R} \mathrm{I} 2$ 种酶切、EPSPS 基因和 CaMV $35 \mathrm{~S}$ 启动子 2 种探针(探针位置见图 1 所示)对它们的 $\mathrm{T}_{2}$ 和 $\mathrm{T}_{3}$ 代阳 性株系进行 Southern blot 检测, 证实这些家系的拷 贝数与 $\mathrm{T}_{0}$ 代检测结果一致(图 4)。进一步选择 4 个 具有单拷贝插入的株系进行了 $\mathrm{T}_{1}$ 代除草剂抗性分离 的检测，即苗期使用田间推荐浓度的 2 倍草甘膦进 行处理, 结果可以看出这些家系的存活单株与死亡 单株符合 3:1 的分离比(表 2), 从而进一步证实了 转基因拷贝数检测结果的准确性。基于上述结果, 从中挑选出 3 个单拷贝插入株系(EPS-2、EPS-6 和 EPS-7)和 2 个双拷贝插入株系(EPS-1 和 EPS-5)用于 后续的试验研究。

\section{3 单拷贝转化株系中 T-DNA 插入位点鉴定}

利用反向 PCR 技术分离 T-DNA 插入位点侧翼 序列, 并将分离的序列与甘蓝型油菜参考基因组序 列进行比对, 确定了这些转化体中 T-DNA 整合到染 色体中的具体位置(图 5)。在 EPS-2 转基因系分离得 到 $1617 \mathrm{bp}$ 的侧翼序列，可以比对到油菜参考基因 组的 chrA05:16529633 处，序列同源性达到 99\%; 该 插入位置位于 BnaA05g21420D 基因的 3'末端。EPS-6 转基因系分离得到 $1578 \mathrm{bp}$ 的侧翼序列, 可以比对 到油菜参考基因组的 chrC02:9519946 处，序列同源 性达到 99\%; 该插入位置位于基因 $B n a C 02 g 14170 D$ 和 BnaC02g14180D 之间的基因间区。EPS-7 转基因 系分离得到 $491 \mathrm{bp}$ 的侧翼序列, 可以比对到油菜参 考基因组的 chrC07:19068559 处，序列同源性达到 $99 \%$; 该插入位置位于基因 BnaC07g $13430 D$ 和 BnaC07g13440D 之间的基因间区。 


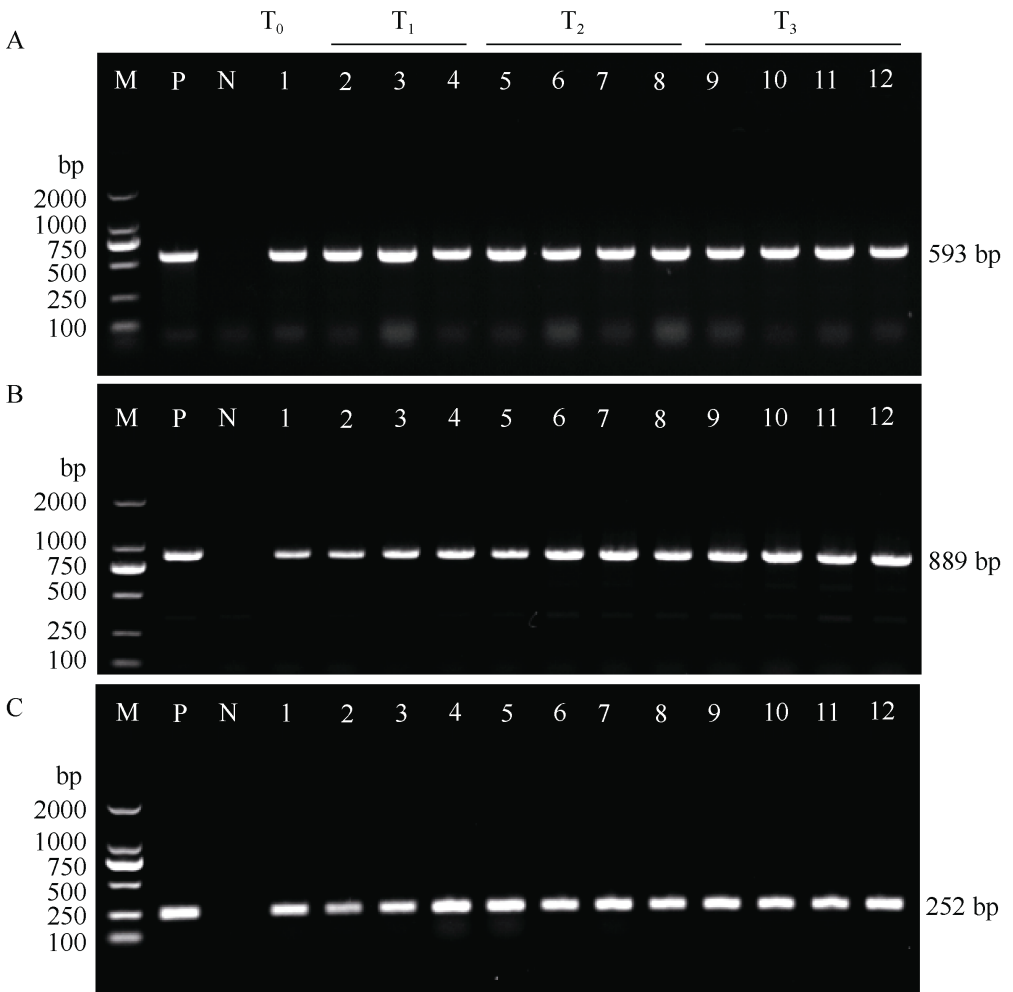

图 2 转 I. variabilis EPSPS 基因植株的 PCR 阳性检测结果

Fig. 2 PCR identification of positive transgenic plants of the I. variabilis EPSPS gene

A: 利用引物对 EPSPS-F/EPSPS-R 检测目的基因 I. variabilis EPSPS 的 PCR 结果; B: 利用引物对 $35 \mathrm{SP}-1 / 35 \mathrm{SP}-2$ 检测 CaMV $35 \mathrm{~S}$ 启动 子元件的 PCR 结果; C: 利用引物对 35 ST-1/35ST-2 检测 CaMV 35 S 终止子元件的 PCR 结果。M 为 $2 \mathrm{~kb}$ DNA marker; P 为 pTGH 质粒(阳 性对照); $\mathrm{N}$ 为转化受体 $\mathrm{J} 9707$ (阴性对照); 1 12 为 $\mathrm{T}_{0}$ 代部分转化植株, 编号分别为 EPS-1 EPS-12。

A: PCR identification of the target gene I. variabilis EPSPS by primer pair EPSPS-F/EPSPS-R; B: PCR identification of the CaMV 35S promoter by primer pair 35SP-1/35SP-2; C: PCR identification of the CaMV 35S terminator by primer pair 35ST-1/35ST-2. M: $2 \mathrm{~kb}$ DNA marker; P: the positive control of pTGH-1plasmid; N: the negative control of J9707; 1-12: the $\mathrm{T}_{0}$ transgenic plants from EPS-1 to EPS-12.

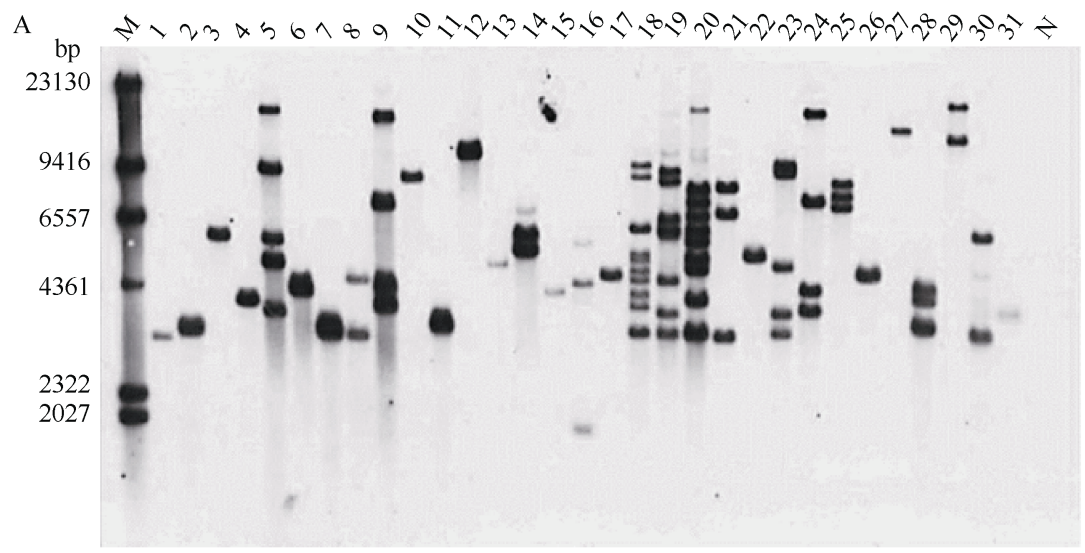

\begin{tabular}{ccc}
\hline $\begin{array}{c}\text { Copy } \\
\text { number }\end{array}$ & $\begin{array}{c}\text { No. of } \\
\text { plants }\end{array}$ & $\begin{array}{c}\text { Percentage } \\
(\%)\end{array}$ \\
\hline 1 & 43 & 44.8 \\
2 & 15 & 15.6 \\
3 & 11 & 11.5 \\
4 & 7 & 7.3 \\
5 & 8 & 8.3 \\
6 & 4 & 4.2 \\
$>7$ & 8 & 8.3 \\
\hline
\end{tabular}

图 3 转 I. variabilis EPSPS 基因 $\mathrm{T}_{0}$ 代阳性植株的 Southern blot 拷贝数检测结果

Fig. 3 Determination of the I. variabilis EPSPS transgenic copy number by Southern blotting analysis in the $T_{0}$-positive transgenic plants

A: Southern blot 检测结果。杂交探针为位于目的基因上的 EPSPS 探针, 基因组 DNA 采用 Hind III 酶切。 M: DNA marker; 1 31: 转基 因阳性植株; 1: EPS-1; 3: EPS-2; 12: EPS-7; 29: EPS-3; 31: EPS-6; N: J9707 (阴性对照)。B: 不同拷贝数的单株统计。

A: detection of Southern blot analysis. The hybrid probe is on the I. variabilis EPSPS gene; the genomic DNA was digested with Hind $\amalg$ before electrophoresis. M: DNA marker; 1-31: the positive transgenic plants; 1: EPS-1; 3: EPS-2; 12: EPS-7; 29: EPS-3; 31: EPS-6; N: J9707 (negative control). B: summary of the copy number of transgenic plants. 
表 2 单拷贝转基因家系草甘膦抗性分离鉴定

Table 2 Glyphosate-resistant segregation analysis of transgenic lines with single T-DNA insertion

\begin{tabular}{cccccc}
\hline $\begin{array}{c}\text { 株系编号 } \\
\text { Line ID }\end{array}$ & $\begin{array}{c}\text { 总株数 } \\
\text { Total plant number }\end{array}$ & $\begin{array}{c}\text { 存活株数 } \\
\text { Number of survived plants }\end{array}$ & $\begin{array}{c}\text { 死亡株数 } \\
\text { Number of dead plants }\end{array}$ & $\begin{array}{c}\text { 期望分离比 } \\
\text { Expected segregated ratio }\end{array}$ & \begin{tabular}{c}
$\chi_{0.05,1}^{2}$ \\
\hline EPS-1
\end{tabular} \\
\hline 50 & 33 & 17 & 19 & $3: 1$ & $3: 1$ \\
EPS-2 & 50 & 31 & 17 & $3: 1$ & 3.84 \\
EPS-4 & 56 & 39 & 15 & $3: 1$ & 0.59 \\
EPS-5 & 49 & 34 & &
\end{tabular}
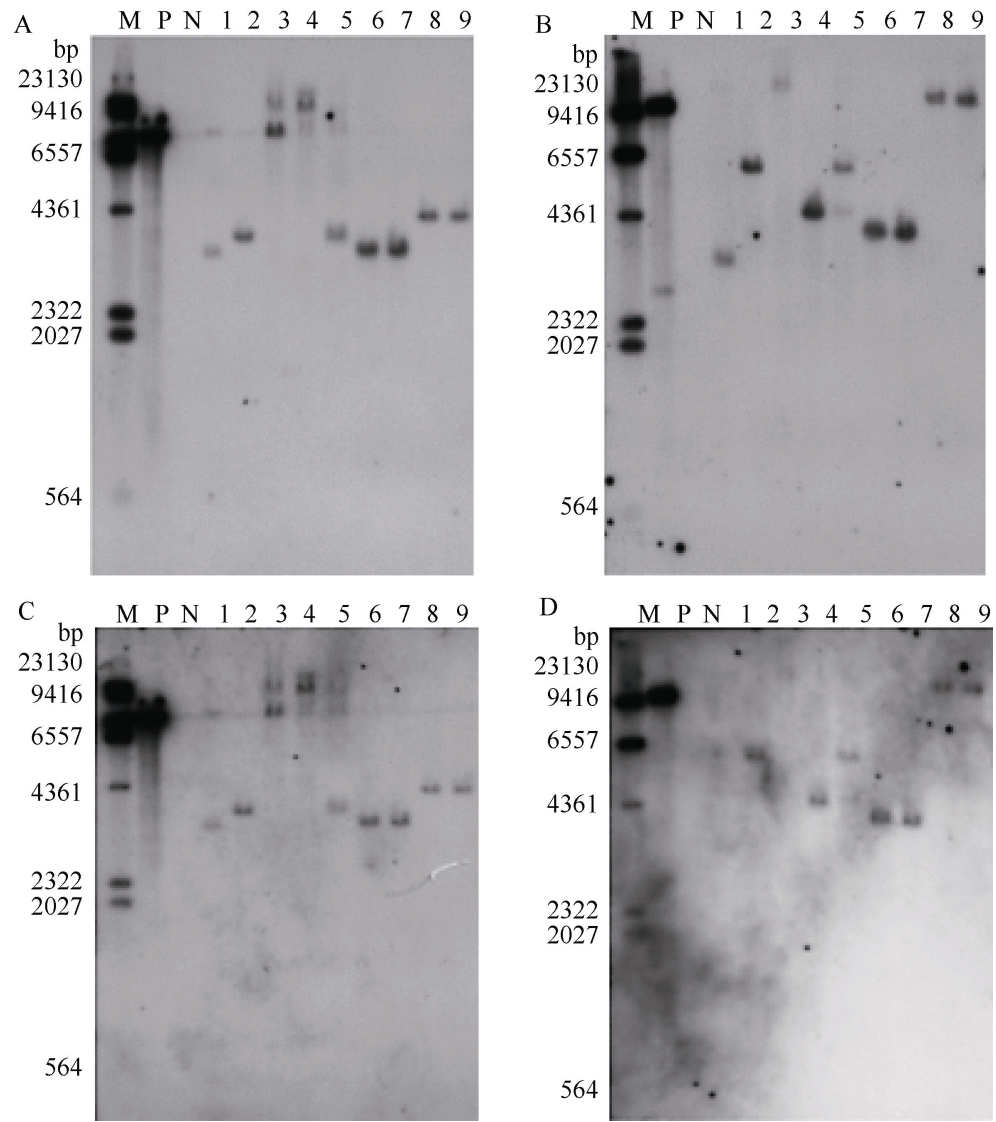

图 $4 T_{2}$ 和 $T_{3}$ 代转 I. variabilis EPSPS 基因植株的 Southern blot 杂交拷贝数检测

Fig. 4 Determination of the $I$. variabilis EPSPS transgenic copy number by Southern blotting analysis in the $T_{2}$ and $T_{3}$ positive transgenic plants

A: EcoR I 酶切、CaMV35S promoter 探针; B: Hind III 酶切、CaMV35S promoter 探针; C: EcoR I 酶切、EPSPS 探针; D: Hind III 酶切、 EPSPS 探针。M: DNA marker; P: pTGH-1 质粒(阳性对照); N: J9707 (阴性对照); 1 9: 转基因阳性植株, 依次为 EPS-1 的 $\mathrm{T}_{2}$ 代植株、 EPS-2 的 $T_{2}$ 代植株、EPS-3 的 $T_{2}$ 代植株、EPS-4 的 $T_{2}$ 代植株、EPS-5 的 $T_{2}$ 代植株、EPS- 6 的 $T_{2}$ 代植株、EPS-6 的 T 3 代植株、EPS-7 的 $T_{2}$ 代植株、EPS-7 的 $T_{3}$ 代植株。

A: detection of Southern blot with the hybrid probe of CaMV35S promoter and EcoR I restriction enzyme; B: detection of Southern blot with the hybrid probe of CaMV35S promoter and Hind $\amalg$ restriction enzyme; C: detection of Southern blot with the hybrid probe of EPSPS gene and EcoR I restriction enzyme; D: detection of Southern blot with the hybrid probe of EPSPS gene and Hind W restriction enzyme. M: DNA marker; P: pTGH-1 plasmid (positive control); N: J9707 (negative control); 1-9: the positive transgenic plants, which are a $\mathrm{T}_{2}$ plant of EPS-1, a $T_{2}$ plant of EPS-2, a $T_{2}$ plant of EPS-3, a $T_{2}$ plant of EPS-4, a $T_{2}$ plant of EPS-5, a $T_{2}$ plant of EPS-6, a $T_{3}$ plant of EPS-6, a $T_{2}$ plant of EPS-7, and a $T_{3}$ plant of EPS-7, respectively.

\section{4 利用特异性 PCR 验证转化株系中的 T-DNA 插入位点}

利用上述分离的侧翼序列信息，分别设计了 EPS-2、EPS-6 和 EPS-7 等油菜转化体的特异性的上 游引物(EPSPS2 F、EPSPS6 F 和 EPSPS7 F), 分别与
载体上的共同下游引物 P5 进行组合, 用于转化体特 异性 PCR 检测(表 1)。

利用转化体特异性引物对这些家系的 4 个不同 世代的植株 $\left(\mathrm{T}_{0} \sim \mathrm{T}_{3}\right)$ 进行 PCR 检测(图 5)发现, 各转 化体从 $\mathrm{T}_{0} \sim \mathrm{T}_{3}$ 世代单株均获得了预期特异性片段, 
而阴性对照 J9707 都没有任何条带。证明 EPS-2、 EPS-6 和 EPS-7 等油菜转化体基因组中整合的 T-DNA 在不同世代间的是稳定的。

\section{5 转基因植株中 I. variabilis EPSPS 基因的表} 达检测

在 $\mathrm{T}_{0}$ 代，分别用 RT-PCR 和 Western blot 检测 了几个转化体的叶片组织中目的基因的表达情 况。从图 7 可以看出, 在 EPS-1、EPS-2、EPS-5、 EPS-6 和 EPS-7 等转化体中可以检测到目的基因
超量表达，而在转化受体 J9707 中检测不到明显 的目的基因表达。

在 $\mathrm{T}_{3}$ 代，利用 qRT-PCR 技术检测了 EPS-2、 EPS-6 和 EPS-7 等转化体在幼叶、成熟叶、子叶、 下胚轴、根、花蕾和种子等不同组织中的基因表达 量(图 7-C)。相对于转化受体 J9707, 3 个转化体在各 个组织中均能检测到目的基因的上调表达; 在不同 转化体中目的基因的表达量有所变异, 其中 EPS-6 在不同组织中都表现出相对较高的表达水平。
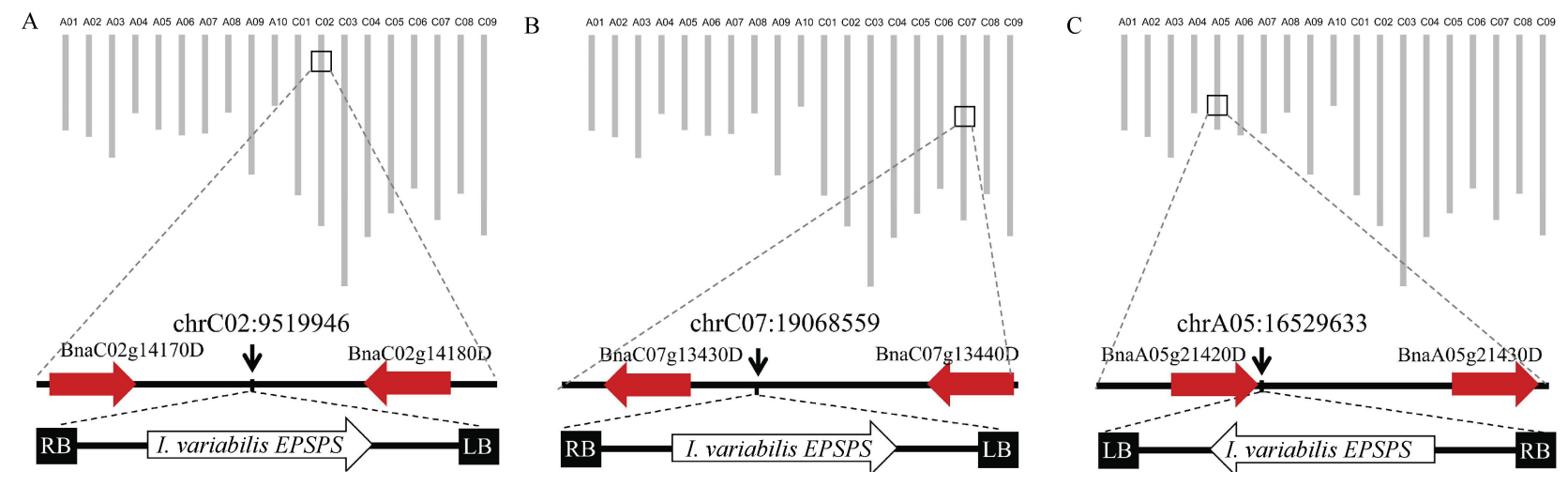

图 5 EPS-2、EPS-6 和 EPS-7 等油菜转化体中 T-DNA 插入位置信息

Fig. 5 Insertion location information of T-DNA of EPS-2, EPS-6, and EPS-7 in the transgenic lines

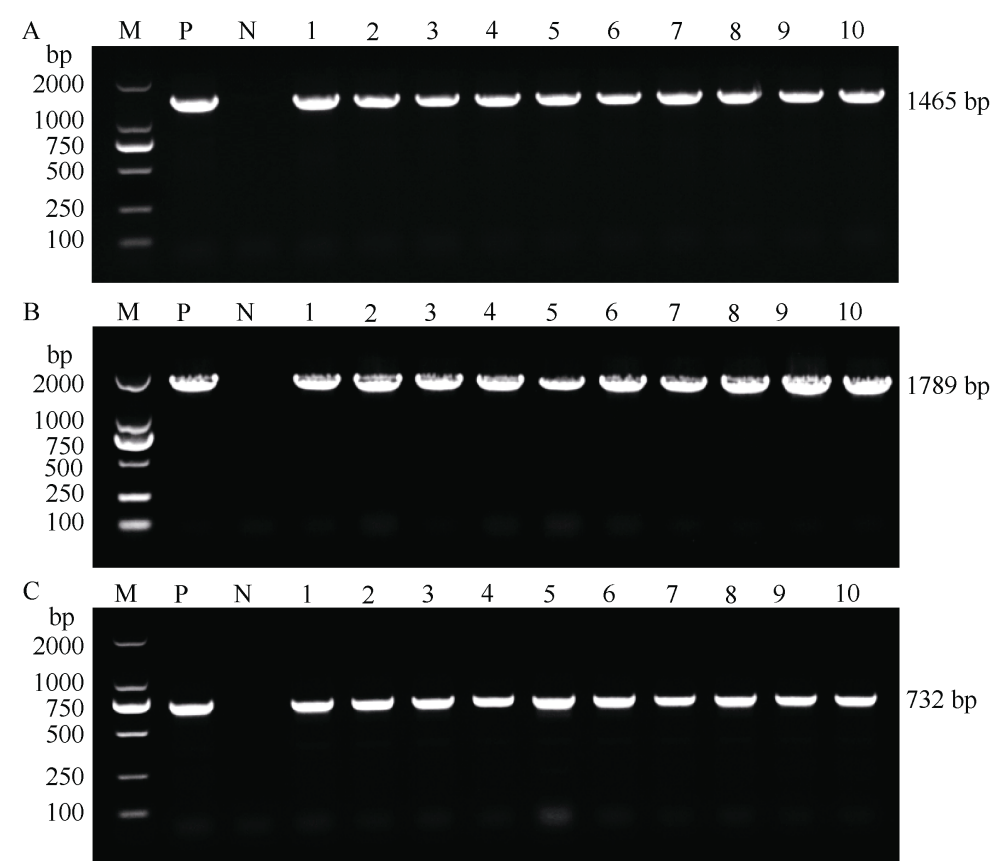

图 6 EPS-2、EPS-6 和 EPS-7 等转基因家系的转化体特异性 PCR 检测结果

Fig. 6 PCR confirmation of the T-DNA insertion in the transgenic lines of EPS-2, EPS-6, and EPS-7 with specific primers

A: EPS-2 转基因家系不同世代材料的转化体特异性 PCR 检测结果, 检测所用引物为 EPSPS-2 F 和 P5; B: EPS-6 转基因家系不同世代 材料的转化体特异性 PCR 检测结果, 检测所用引物为 EPSPS6 F 和 P5; C: EPS-7 转基因家系不同世代材料的转化体特异性 PCR 检测 结果, 检测所用引物为 EPSPS7F 和 P5。其中, $\mathrm{M}$ 为 $2 \mathrm{~kb}$ DNA marker; $\mathrm{P}$ 为 pTGH-1 质粒(阳性对照); $\mathrm{N}$ 为转化受体 J9707 (阴性对照); 1 为 $T_{0}$ 代植株; $2 \sim 4$ 为 $T_{1}$ 代抗性植株; 5 7 为 $T_{2}$ 代抗性植株; $8 \sim 10$ 为 $T_{3}$ 代抗性植株。

A: PCR confirmation of the T-DNA insertion in the transgenic line of EPS-2 with specific primer pair EPSPS2 F/P5. B: PCR confirmation of the T-DNA insertion in the transgenic line of EPSPS6 with specific primer pair EPSPS6 F/P5. C: PCR confirmation of the T-DNA insertion in the transgenic line of EPS-7 with specific primer pair EPSPS7 F/P5. M: 2 kb DNA marker; P: pTGH-1 plasmid (positive control); N: J9707 (negative control); 1: $\mathrm{T}_{0}$-transgenic plant; 2-4: $\mathrm{T}_{1}$-transgenic plant; 5-7: $\mathrm{T}_{2}$-transgenic plant; 8-10: $\mathrm{T}_{3}$-transgenic plant. 


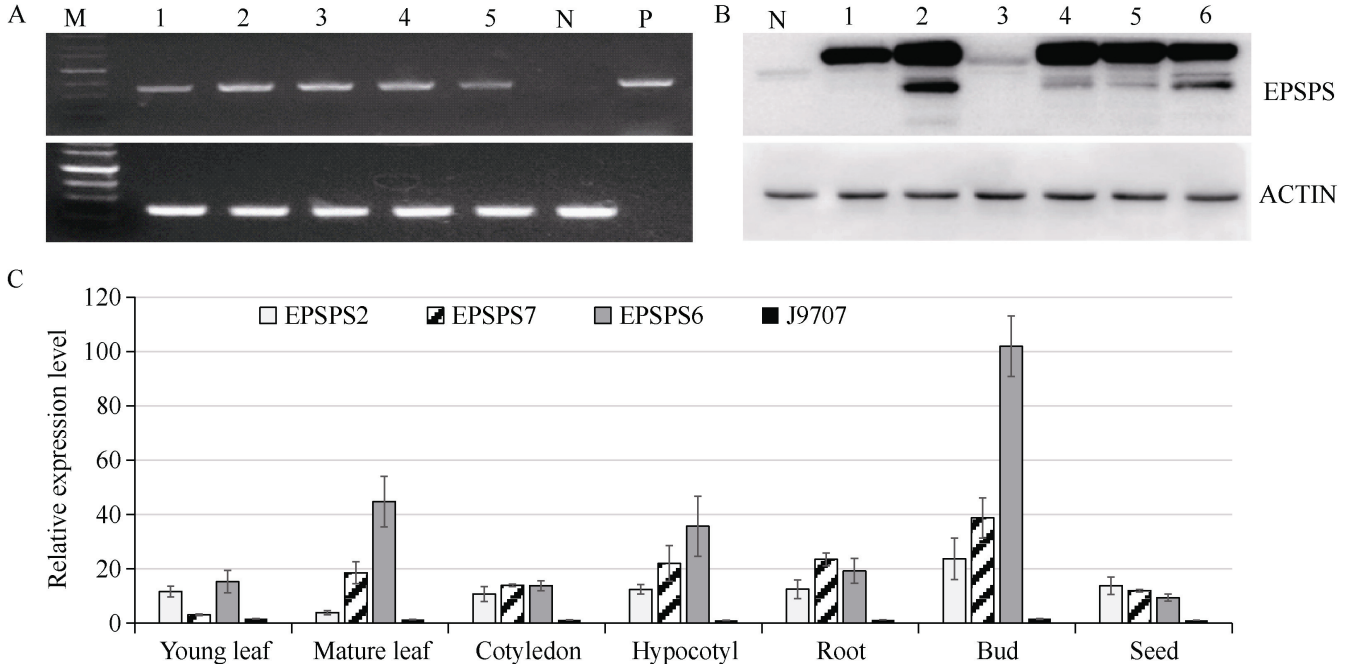

图 7 转 I. variabilis EPSPS 阳性株系的表达检测

Fig. 7 Expression analysis of the transgenic lines of I. variabilis EPSPS

A: RT-PCR 检测目的基因在 $\mathrm{T}_{0}$ 代株系叶片中的 RNA 表达水平。其中, $\mathrm{M}$ 为 $3 \mathrm{~kb}$ DNA marker; 1 5 依次为 EPS-1、EPS-6、EPS-7、EPS-2 和 EPS-5 等转化系; N: J9707 (阴性对照); P: pTGH-1 质粒(阳性对照)。B: Western blot 检测目的基因在 $\mathrm{T}_{0}$ 代株系叶片中的蛋白表达水 平。其中, N: J9707 (阴性对照); 1 6 依次为 EPS-1、EPS-6、EPS-36、EPS-7、EPS-2 和 EPS-5 转化系。C: qRT-PCR 检测目的基因在 T 3 代株系的不同组织中相对表达量。油菜 Actin2 (AF111812)为内参基因。

A: the RNA expression levels of the target gene in the leaf of $\mathrm{T}_{0}$-positive transgenic lines detected by RT-PCR. M: 3 kb DNA marker; 1-5: the positive transgenic lines of EPS-1, EPS-6, EPS-7, EPS-2, and EPS-5, respectively; N: J9707 (negative control); P: pTGH-1 (positive control). $\mathrm{B}$ : the protein expression level of the target gene in the leaves of the $\mathrm{T}_{0}$-positive transgenic lines detected by Western blot. $\mathrm{N}$ : J9707 (negative control); 1-6: the positive transgenic lines of EPS-1, EPS-6, EPS-36, EPS-7, EPS-2, and EPS-5, respectively. C: the relative expression of the target gene in different tissues of the $\mathrm{T}_{3}$-positive transgenic lines detected by qRT-PCR. Actin2 (AF111812) in rape is an internal reference gene.

\section{6 转基因植株的除草剂抗性鉴定}

在 $T_{1}$ 代, 对 EPS-2、EPS-6 和 EPS-7 等转化体 的草甘膦抗性进行了初步评价，以 $\mathrm{J} 9707$ 和常规品 种中双 11 号为阴性对照, 苗期使用田间推荐浓度的 2 倍草甘膦进行了处理。由图 8 可以看出, 2 种阴性 对照在处理后药害严重, $20 \mathrm{~d}$ 左右植株完全死亡; 而
各转化体都表现出对草甘膦的抗性。EPS-6 在处理 后几乎未见明显的药害, 与对照条件下(喷施等量清 水)的植株生长相似，表现出很好的草甘膦抗性; EPS-2 和 EPS-7 等转化体也表现较好的抗性, 但是 比对照条件下的植株生长弱小，表现出一定程度的 药害。

Treatment with 2-fold dosage of glyphosate

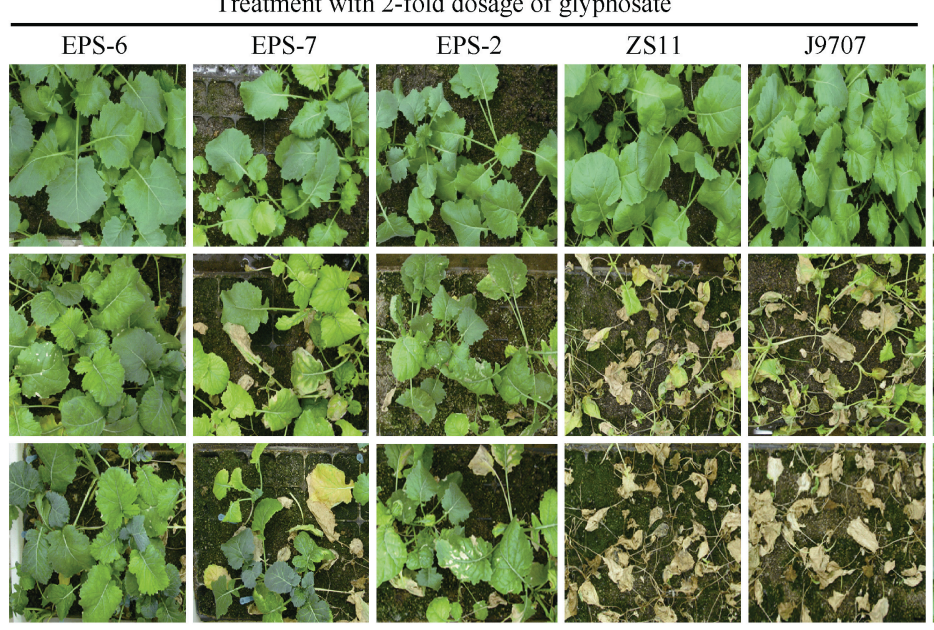

Control (treatment with water)

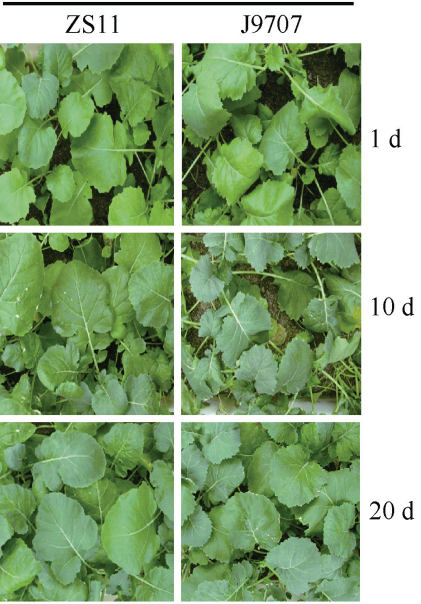

图 8 转 I. variabilis EPSPS 基因 $\mathbf{T}_{1}$ 代株系喷施草甘膦处理下的抗性表现

Fig. 8 Phenotypes of $T_{1}$ transgenic plants of $I$. variabilis EPSPS under the treatments of glyphosate 
为进一步确定目标除草剂抗性的功能稳定性, 在 $\mathrm{T}_{3}$ 代对 EPS-1、EPS-2、EPS-5、EPS-6 和 EPS-7 等株系进行苗期的 4 种草甘膦浓度的喷施处理 $(0$ 倍、 1 倍、2 倍和 4 倍), 以 $\mathrm{J} 9707$ 为对照。从图 9 可以看
出，阴性对照 $\mathrm{J} 9707$ 在处理后药害严重，在 4 倍浓度 喷施处理后第 4 周完全死亡; 而各转化体在 4 倍浓 度喷施处理后仍未见明显的药害发生, 都表现出很 好的草甘膦抗性。

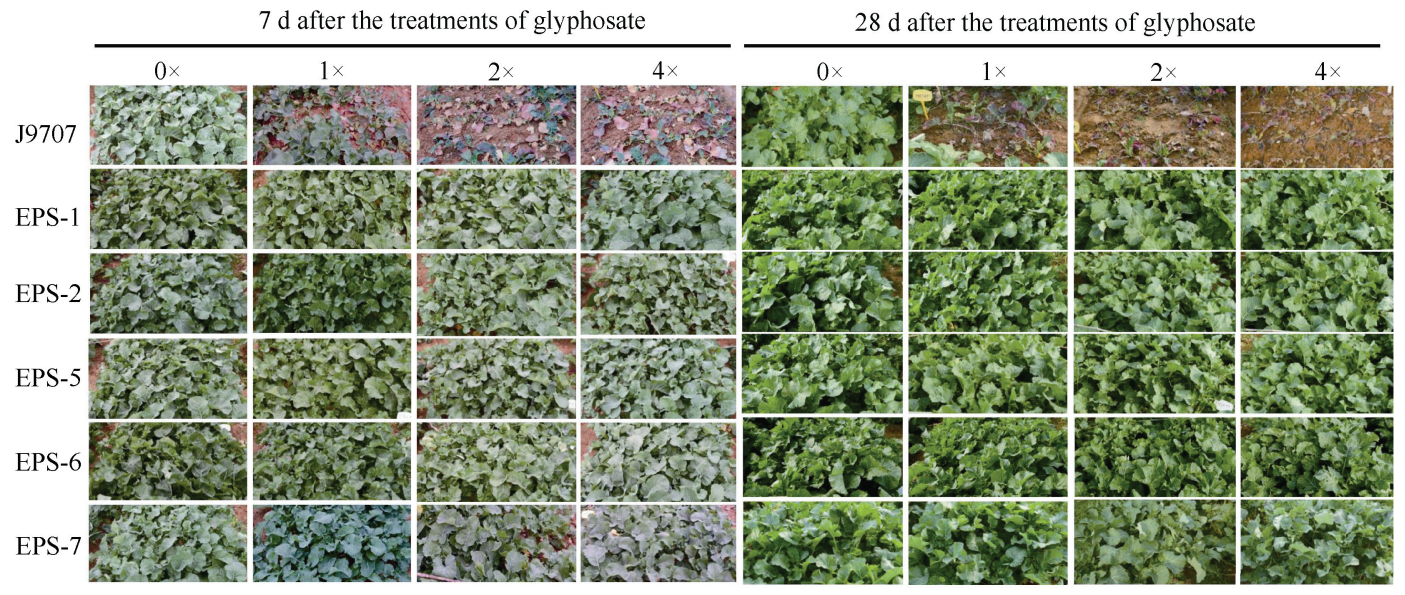

图 9 转 I. variabilis EPSPS 基因 $\mathrm{T}_{3}$ 代株系苗期喷施不同浓度草甘膦处理下的抗性表现

Fig. 9 Phenotypes of $T_{3}$ transgenic plants of $I$. variabilis EPSPS under the treatments with different concentrations of glyphosate at seedling stage

\section{3 讨论}

根据国际农业生物技术应用服务组织 (International Agricultural Biotechnology Application Service Organization, ISAAA) 提供的数据, 截至 2020 年, 全世界共有 70 个国家和地区种植或进口了 转基因作物，全球转基因作物种植面积达 1.917 亿 公顷，涉及 32 个作物种类、526 项转基因作物事件。 其中, 除草剂耐受性的转基因事件达 341 项, 占总 转基因作物事件的 $64.8 \%$, 而抗除草剂转基因油菜 转化事件有 38 项, 占转基因油菜转化事件的 $90.5 \%$ 。 目前应用的抗除草剂转基因油菜主要有抗草甘膦、 抗草铵膦和抗溴苯氰等类型, 其中种植面积最广的 是抗草甘膦。油菜中广泛应用的的抗草甘膦基因绝 大部分来自于孟山都和杜邦等国外生物技术公司, 其中孟山都公司从根癌农杆菌 CP4 菌株中获得的抗 草甘膦 CP4-epsps 基因应用最为成功; 该酶对草甘 膦不敏感, 对 EPSPS 催化的底物 5-磷酸烯醇式丙 酮酸(5-phosphoenolpyruvate, PEP)具有很高的亲和 力; 因此, 它可以取代植物的内源 EPSPS 合成酶体 系, 使莽草酸途径正常进行, 从而达到抗草甘膦的 效果 ${ }^{[15,22]}$ 。本研究使用的 I. variabilis EPSPS 是从细 菌 I. variabilis 中克隆到的一种新型的抗草甘膦基 因 $^{[11]}$ ，与已获得转基因批准的 CP4-epsps、玉米 EPSPS 突变体以及 $G R G 23$ 突变体中的 EPSPS 基因 的氨基酸序列同源性分别只有 $27.1 \%$ 、 $33.5 \%$ 和
$31.5 \%{ }^{[24]}$ 。因此, I. variabilis EPSPS 是一种具有完全 自主知识产权的新型抗草甘膦基因 ${ }^{[19]}$ 。

本研究成功将该基因转入到甘蓝型油菜中, 获 得了一批单拷贝的转基因株系。通过多代的分子特征 检测证实该基因稳定整合到油菜基因组中，在多个 世代间可以检测到目的基因的超量表达。在 $\mathrm{T}_{1}$ 代对 单拷贝家系 EPS-2、EPS-6 和 EPS-7 进行草甘膦喷施 处理发现, 转 I. variabilis EPSPS 的不同家系均表现 出草甘膦抗性, 其中 EPS-6 家系抗性表现最优(图 8), 这与该家系中目标基因在叶片等组织中的相对表达 量最高一致(图 9), 显示提高该目的基因的表达量有 利于增强转基因油菜的草甘膦抗性水平。这 3 个家系 中, EPS-6 和 EPS-7 的 T-DNA 都位于基因间区, 理论 上对插入位点附近的基因表达不会产生太大影响, 是比较理想的转化株系; 而 EPS-2 的 T-DNA 插入在 BnaA05g21420D 基因的 $3^{\prime}$ 末端, 可能会影响该基因 表达, 还需要后续的试验进行验证。在 $\mathrm{T}_{3}$ 代, 进一步 对这 3 个单拷贝家系和 2 个双拷贝插入的转基因家系 (EPS-1 和 EPS-5)进行了 0 4 倍田间推荐使用剂量的 草甘膦喷施处理, 表明它们都具有很好的抗性。因此, I. variabilis EPSPS 基因有望作为一个新型的草甘膦 抗性基因应用到油菜抗除草剂品种培育中。

\section{4 结论}

将来自放线菌属变异白蚁菌中的新型抗除草剂 
基因 I. variabilis EPSPS 通过农杆菌介导的遗传转化 法导入甘蓝型油菜中, 获得了 126 株转基因阳性单 株。通过对外源插入片段的拷贝数、整合稳定性、 表达稳定性和目标除草剂抗性的稳定性等特性的分 析，篮选出优异的新型抗广谱性除草剂草甘膦转基 因株系, 将为我国抗除草剂转基因油菜品种培育提 供优异的种质资源。

\section{References}

[1] 王汉中. 我国油菜产业发展的历史回顾与展望. 中国油料作 物学报, 2010, 32: 300-302.

Wang H Z. Historical review and prospect of rapeseed industry development in China. Chin J Oil Crop Sci, 2010, 32: 300-302 (in Chinese with English abstract).

[2] 官春云. 优质油菜生理生态和现代栽培技术. 北京: 中国农业 出版社, 2013. pp 192-219.

Guan C Y. Physiological Ecology and Modern Cultivation Techniques of High-Quality Rapeseed. Beijing: China Agriculture Press, 2013. pp 192-219 (in Chinese).

[3] Dill G M. Glyphosate-resistant crops: history, status and future. Pest Manage Sci, 2010, 61: 219-224.

[4] 赵平. 2015 年全球农药市场概况及发展趋势. 农药, 2017, 56(2): 79-85.

Zhao P. Overview and development trend of global pesticide market in 2015. Pesticide, 2017, 56(2): 79-85 (in Chinese with English abstract).

[5] Li H T, Li J J, Zhao B, Wang J, Yi L C, Liu C, Wu J S, King G J, Liu K D. Generation and characterization of tribenuron-methyl herbicide-resistant rapeseed (Brasscia napus) for hybrid seed production using chemically induced male sterility. Theor Appl Genet, 2015, 128: 107-118.

[6] 魏松红, 纪明山, 张希科, 孙桂玲. 应用诱变法篮选抗草甘膦 水稻植株. 农药, 2006, 45(11): 43-44.

Wei S H, Ji M S, Zhang X K, Sun G L. Selection of glyphosate-resistant rice with mutation. Pesticide, 2006, 45(11): 43-44 (in Chinese with English abstract).

[7] 张俐俐, 谷维, 雷勃钧, 吕晓波, 李铁. 应用化学诱变法篮选 抗草甘膦大豆突变株系. 大豆科学, 2009, 28: 938-940.

Zhang L L, Gu W, Lei B J, Lyu X B, Li T. Glyphosate resistant mutant strain of soybean filtered by chemomorphosis. Soybean Sci, 2009, 28: 938-940 (in Chinese with English abstract).

[8] Padgette S R, Kolacz K H, Delannay X, Re D B, LaVallee B J, Tinius C N, Rhodes W K, Otero Y I, Barry G F, Eichholtz D A. Development, identification, and characterization of a glyphosate-tolerant soybean line. Crop Sci, 1995, 35: 1451-1461.

[9] Kahrizi D, Salmanian A H, Afshari A, Moieni A, Mousavi A. Simultaneous substitution of Gly96 to Ala and Ala183 to Thr in 5-enolpyruvylshikimate-3-phosphate synthase gene of E. coli (k12) and transformation of rapeseed (Brassica napus L.) in order to make tolerance to glyphosate. Plant Cell Rep, 2007, 26: 95-104.

[10] Main C L, Jones M A, Murdock E C. Weed response and tolerance of enhanced glyphosate-resistant cotton to glyphosate. $J$ Cotton Sci, 2007, 11: 104-109.

[11] Green J M, Hale T, Pagano M A, Andreassi J L, Gutteridge S A. Response of 98140 corn with gat4621 and hra transgenes to glyphosate and $A L S$-inhibiting herbicides. Weed $S c i, 2009,57$ : 142-148.

[12] Comai L, Facciotti D, Hiatt W R, Thompson G, Rose R E, Stalker D M. Expression in plants of a mount aroA gene from Salmonella typhimurium confers tolerance to glyphosate. Nature, 1985, 317: 741-744.

[13] Barry G, Kishore G, Padgette S, Taylor M, Kolacz K, Weldon M, Re D, Fincher K, Hallas L. Inhibitors of amino acid biosynthesis: strategies for imparting glyphosate tolerance to crop plants. Curr Top Plant Physiol, 1992, 7: 139-145.

[14] 陈家华, 潘良文, 沈禹飞, 胡永强, 陶军. 转基因抗草甘膦油 菜籽中草甘膦氧化还原酶基因的检测方法研究. 中国油料作 物学报, 2001, 23: 63-67.

Chen J H, Pan L W, Shen Y F, Hu Y Q, Tao J. Detection of glyphosate oxidoreductase gene in transgenic rapeseed resistant to glyphosate. Chin J Oil Crop Sci, 2001, 23: 63-67 (in Chinese with English abstract).

[15] Yang X, Li L, Jiang X Q, Wang W, Cai X X, Su J, Wang F, Lu B R. Genetically engineered rice endogenous 5-enolpyruvoylshikimate-3-phosphate synthase (EPSPS) transgene alters phenology and fitness of crop-wild hybrid offspring. Sci Rep, 2017, 7: 6834.

[16] Li J, Meng X B, Zong Y, Chen K L, Zhang H W, Liu J X, Li J Y, Gao C X. Gene replacements and insertions in rice by intron targeting using CRISPR-Cas9. Nat Plants, 2016, 2: 139.

[17] Aaron W H, Raj D C, Tomas C, Andrew M M, Anupama V, Adam B, Colby G S, Rebecca B, Daniel F V, Nigel J T. Allele exchange at the EPSPS locus confers glyphosate tolerance in cassava. Plant Biotechnol J, 2018, 16: 1275-1282.

[18] Cui Y, Huang S Q, Liu Z D, Yi S Y, Zhou F, Chen H, Lin Y J. Development of novel glyphosate-tolerant japonica rice lines: a step toward commercial release. Front Plant Sci, 2016, 7: 1218.

[19] 刘子铎, 易沭远, 林拥军, 张利莉, 吴高兵. 一种分离的 5-烯 醇丙酮莽草酸-3-磷酸合酶基因. CN103834674, 2016-2-23.

Liu Z Y, Yi M Y, Lin Y J, Zhang L L, Wu G B. A isolated 5enolpyruvyl-shikimate-3-phosphate synthase gene. CN103834674, 2016-2-23 (in Chinese).

[20] Yi S Y, Wu G B, Lin Y J, Hu N, Liu Z D. Characterization of a new type of glyphosate-tolerant 5-enolpyruvyl shikimate-3phosphate synthase from Isoptericola variabilis. $J$ Mol Catal B Enzym, 2015, 111: 1-8.

[21] Zhou Y, Wang H, Gilmer S, Whitwill S, Keller W, Fowke L C. Control of petal and pollen development by the plant cyclindependent kinase inhibitor ICK1 in transgenic Brassica plants. Planta, 2002, 215: 248-257.

[22] 李杰华. 抗广谱性除草剂转基因油菜创制及抗性评价. 华中 农业大学硕士学位论文, 湖北武汉, 2018.

Li J H. Development and Evaluation of Transgenic Rapeseed with Broad Spectrum Herbicide Resistant Gene. MS Thesis of Huazhong Agricultural University, Wuhan, Hubei, China, 2018 (in Chinese with English abstract).

[23] Fan C C, Wu Y D, Yang Q Y, Yang Y, Meng Q W, Zhang K Q, Li J G, Wang J F, Zhou Y M. A novel single-nucleotide mutation in a CLAVATA3 gene homologue controls a multilocular silique trait in Brassica rapa L. Mol Plant, 2014, 7: 1788-1792.

[24] Dong Y F, Jin X, Tang Q L, Zhang X, Yang J T, Liu X J, Cai J F, Zhang X B, Wang X J, Wang Z X. Development and event-specific detection of transgenic glyphosate-resistant rice expressing the G2-EPSPS gene. Front Plant Sci, 2017, 8: 885. 